\title{
THE INFLUENCE OF ON- AND OFF-FARM SURFACE WATER INVESTMENT ON GROUNDWATER EXTRACTION FROM AN AGRICULTURAL LANDSCAPE
}

\author{
KENT KOVACS* \\ Agricultural Economics and Agribusiness, University of Arkansas, Fayetteville, Arkansas \\ ALVARO DURAND-MORAT \\ Agricultural Economics and Agribusiness, University of Arkansas, Fayetteville, Arkansas
}

\begin{abstract}
The use of surface water to replace groundwater for irrigation is often viewed as an effective approach for reducing groundwater overdraft on an agricultural landscape. However, the availability of surface water does not necessarily lead to groundwater conservation in practice. The expected increase in the aquifer volume in the presence of surface water does not occur unless the off-farm water price is low enough to generate a significant shift away from groundwater. There is a change in the crop pattern toward more irrigation-intensive crops, and the net effect can be a rise in groundwater extraction.
\end{abstract}

Keywords. Groundwater conservation, irrigation, surface water delivery

JEL Classifications. Q15, Q24, Q25

\section{Introduction}

Overdraft of groundwater for irrigation causes the depletion of shallow aquifers, and the rise in groundwater pumping costs causes economic returns to fall. One solution to the problem of groundwater overdraft is the use surface water instead of groundwater for irrigation. However, precipitation that generates surface water often occurs at times of the year when the demand for irrigation is low, and the surface water must then be stored until the demand for irrigation is high. The storage can be a reservoir built on the farm or off-farm storage units that distribute water to the farm through a canal system. The use of surface water through on- or off-farm sources affects the aquifer volume and irrigation costs, and this influences the crops grown and economic returns from the agricultural

This project was supported by the Arkansas Rice Research Promotion Board and the Arkansas Soybean Promotion Board.

*Corresponding author e-mail: kkovacs@uark.edu 
landscape. A rise in the aquifer may not occur if the price for surface water is too high to significantly reduce groundwater use and more irrigation-intensive crops are grown. Amidst the backdrop of changes in irrigated and nonirrigated crops, we investigate how alternative prices for off-farm surface water in conjunction with on-farm surface water and irrigation practices influence the long-run aquifer volume and economic returns.

We develop a spatial model of groundwater use over three decades to determine (1) the off-farm water demand curve for an agricultural landscape in the presence of on-farm water storage and efficient irrigation practices, and (2) how conjunctive surface water use, efficient irrigation practices, and water conservation policies affect the conservation of the aquifer with endogenous changes in the crop mix on the landscape. The potential shape and position of the demand for off-farm water helps policy makers gauge whether particular prices for off-farm water can alleviate pressure on the aquifer. The intended aim of surface water and efficient irrigation practices is to conserve the aquifer, but increases in irrigation-intensive crops can ultimately increases the rate of groundwater overdraft.

Investment in the development of surface water storage for irrigation can be expensive in comparison with investment in greater irrigation efficiency through irrigation-scheduling devices and pressurized irrigation systems, but the return from these investments have to be weighed against the costs (Schaible and Aillery, 2012). Ample surface water in the off-season that can be cheaply stored and easily transported to farms may be preferred to costly improvements in irrigation efficiency. The physical characteristics of the land also affect the suitability of irrigation system investments (Caswell and Zilberman, 1986). Gravity systems are better when fields have flatter slopes and soils with low infiltration rates, whereas pressurized systems have an advantage on irregularly shaped fields with steeper slopes and soils with high infiltration rates. An agricultural landscape above an abundant aquifer with significant natural recharge may not need any investments in irrigation so long as groundwater pumping is cheap. Increases in irrigation-intensive crop acreage though will likely make some irrigation investment necessary.

The model we use has spatially explicit aquifer, irrigation, and economic components to analyze how crop and irrigation source decisions change the demand for off-farm farm water. Other than groundwater, on-farm reservoirs with tailwater recovery that reuse water throughout the season provide a backstop source of water as an alternative to off-farm water. The model allows for more efficient irrigation practice adoption that reduces the per acre irrigation water demand for the crops, and this may shift the off-farm demand curve inward unless irrigated acreage expands significantly. The availability of onand off-farm surface water and efficient irrigation practices changes the mix of irrigated and nonirrigated crops, and this leaves the outcome for the aquifer uncertain. A shift toward an irrigation-intensive crop like rice when surface 
water becomes available may lead to a decline in the aquifer. The aquifer model evaluates how the flow of water within the aquifer attributable to well pumping at each site responds to aquifer thickness, hydroconductivity, and proximity to other wells.

Our model is applied to the lower Mississippi River basin (LMRB), a region with one of the fastest increases in irrigated acreage (Schaible and Aillery, 2012). Arkansas is the largest consumer of water from the Mississippi River valley alluvial aquifer, and the current rate of withdrawals from the aquifer exceed recharge because irrigated acres increase each year (Arkansas Natural Resources Commission [ANRC], 2012). Annual precipitation averages 50 inches per year, but the lack of timely rainfall and the shift to irrigated acres means the current rate of groundwater pumping persists (National Oceanic and Atmospheric Administration [NOAA], National Centers for Environmental Information, 2014). A number of counties in the LMRB region of Arkansas have experienced declines in groundwater so significant that they are designated as critical groundwater areas, and projections indicate only about $20 \%$ of irrigation water demand can be met with groundwater by 2050 (ANRC, 2014). Federal cost-share programs contribute to the implementation of on-farm storage reservoirs, tailwater recovery ditches, and irrigation practices such as special furrow techniques that modify soil-moisture infiltration.

A large literature exists on groundwater management to slow the rate of withdrawals that include payments to convert irrigated crop production to nonirrigated crop production (Ding and Peterson, 2012), tradable groundwater permits (Kuwayama and Brozovic, 2013), and cost share for the adoption of irrigation practices (Huffaker and Whittlesey, 1995). However, the influence of surface water storage on the long-run depletion of the aquifer and the change in crop mix is mostly unexplored. A substitution toward irrigation-intensive crops is possible when reliable surface water is available, and this may cause greater depletion of the aquifer. Moore, Gollehon, and Carey (1994) find a significant long-run response in water use to increases in groundwater pumping cost through changes in cropping patterns for the major crops in the western United States. Moreover, the choices for on-farm storage construction, irrigation practices, and crop mix affect the quantity of off-farm surface water demanded at alternative prices for the off-farm water. The demand curve for off-farm water matters to policy makers who must justify the costly infrastructure projects, such as dams and pumping stations, required to make off-farm water available to farmers.

Previous studies find that the use of on-farm reservoirs in the study region become worthwhile when the depth to the aquifer is greater than 60 feet and the saturated thickness of the aquifer is less than 30 feet (Kovacs and Mancini, 2017; Wailes et al., 2004). Farmers with land over these depleted aquifers are likely to either purchase off-farm water or build on-farm reservoirs. Hill et al. (2006) find that a government cost-share program for on-farm reservoirs and irrigation 
pipeline in conjunction with off-farm water availability is the best policy for maintaining farm incomes on a rice landscape. There is no modeling, however, of changes in crop choice or the size of the on-farm reservoirs or of the spatial connectivity of the aquifer that could alter these findings.

In the next section, we describe the land and irrigation components of the model for the farm net returns optimization used to derive the off-farm water demand curve followed by a description of the sensitivity analyses and policy options. After this, the data for the Arkansas delta application are presented. Lastly, we have the results of the model scenarios and a conclusion with a summary of key model findings and future research directions.

\section{Methods}

The land cover of the agricultural landscape includes crops and on-farm reservoirs. The chosen crops generate economic returns, but irrigation from wells depletes groundwater. The landscape is spatially heterogeneous because of differences in long-term investment in farm practices, soil types, and access to water resources. A time horizon $T$ is chosen for a single generation of farmers to observe how depletion of the aquifer influences production decisions, and a grid of $m$ cells (sites) represents spatial differences.

The major crops include irrigated rice, soybean, corn, and cotton; nonirrigated sorghum and soybean; and double-cropped irrigated soybean with winter wheat. These crops may use any of $K$ irrigation practices of the study region that include conventional (furrow for crops other than rice and flood for rice), center pivot, computerized poly-pipe hole selection, surge, land leveling, alternate wet-dry, and multiple inlet. There are $n$ possible land cover types $j$ using any of the irrigation practices $k$ at the end of period $t$ as denoted by $L_{i j k t}$ for site $i$ that include each of the crops and reservoirs that have tailwater recovery. We refer to the on-farm reservoir use as $j=R$, and the cumulative amount of land in reservoirs in period $t$ is $L_{i R t}$. At the end of each period $t$, which is a 10-year interval, we assume any land cover $j$ can become another crop or an on-farm reservoir with tailwater recovery. A profit-maximizing farmer may switch land out of irrigated crops into nonirrigated crops in response to declining groundwater availability at the end of each period.

The initial land availability equals the sum of the land covers chosen for site $i$ at any time $t$ (equation 1).

$$
\sum_{j}^{n} \sum_{k}^{K} L_{i j k t}=\sum_{j}^{n} \sum_{k}^{K} L_{i j k 0}, \text { for } j=\text { crops, on-farm reservoirs }
$$

\subsection{Irrigation}

The average annual irrigation that crop $j$ receives to supplement precipitation, $w d_{j}$, is the crop demand for irrigation in acre-feet. A reduction in the irrigation water applied to the crop, known as deficit irrigation, is not explored because 
optimization becomes intractable, and there is empirical evidence that perfectly inelastic demand for irrigation water is a reasonable assumption (Wang and Segarra, 2011). The groundwater stored in the aquifer beneath site $i$ at the end of the period $t$ is $A Q_{i t}$. There are three potential sources of irrigation water for producers. Either the producer purchases water from off-farm sources, $O F W_{i t}$, constructs and pumps water from on-farm reservoirs, $R W_{i t}$, or pumps groundwater from wells, $G W_{i t}$. There is recharge of the groundwater, $n r_{i}$, that occurs naturally from precipitation, streams, and underlying aquifers each period.

Equation (2) shows the acre-feet of water stored in an acre reservoir (Kovacs et al., 2014) as

$$
\left(\omega_{\max }+\omega_{\min }\right)-\frac{\omega_{\max }}{\sum_{j}^{n} \sum_{k}^{K} L_{i j k 0}} L_{i R t},
$$

which includes, $L_{i R t}$, as the acres in reservoirs at time $t$, and the total acreage at site $i, \sum_{j}^{n} \sum_{k}^{K} L_{i j k 0}$. If the reservoir occupies the entire site $i$ and only the rainfall fills the reservoir, then the low-end acre-feet of water that fills each reservoir acre is $\omega_{\min }$. If the reservoir is less than the size of the site, then recovery of the runoff and rainfall fills the reservoir to a high-end capacity in acre-feet per reservoir acre of $\left(\omega_{\max }+\omega_{\min }\right)$. We do not account for annual variability in the evaporation, leakage, and the timing of rainfall within a growing season, which could influence $\omega_{\max }$ and $\omega_{\min }$ for the reservoir.

The intensity of well pumping across the landscape influences aquifer depletion and varies over space. The proportion of the underground flow into the aquifer at site $k$ and out of site $i$ when an acre-foot is pumped from a well at site $k$ is $p_{i k}$, which depends on the distance and the lateral speed of underground water movement based on the soil profiles observed between sites (Kovacs et al., $2015)$. This means the groundwater that leaves site $i$ is $\sum_{k}^{m} p_{i k} G W_{k t}$. We assume pumps have the same efficiency and power units to deliver a fixed amount of water per minute.

The water used for irrigation must be less than the water available from off-farm sources, reservoirs, and wells (equation 3), and equation (4) indicates the water stored in the reservoirs must be greater than the water used from the reservoirs. The aquifer volume in the previous period less the spatially weighted proportion of water pumped from the surrounding sites plus natural recharge equals the current aquifer volume (equation 5). The cost of pumping groundwater at a site, $G C_{i t}$, depends on the cost to lift an acre-foot of water by 1 foot, $c^{p}$, and the initial depth to the groundwater, $d p_{i}$. The depletion of the aquifer volume $\left(A Q_{i 0}-A Q_{i t}\right)$ divided by the area of the site, $\sum_{j}^{n} \sum_{k}^{K} L_{i j k 0}$, indicates how much the depth to the aquifer increases. Capital costs per acre-foot for the well, which accounts for new well drilling in response to aquifer decline, 
are represented by $c^{c}$ (equation 6).

$$
\begin{gathered}
\sum_{j=1}^{n} w d_{j} L_{i j t} \leq G W_{i t}+O F W_{i t}+R W_{i t} \\
R W_{i t} \leq\left(\left(\omega_{\max }+\omega_{\min }\right)-\frac{\omega_{\max }}{\sum_{j}^{n} \sum_{k}^{K} L_{i j k 0}} L_{i R t}\right) L_{i R t} \\
A Q_{i t}=A Q_{i(t-1)}-\sum_{k}^{m} p_{i k} G W_{k t}+n r_{i} \\
G C_{i t}=c^{c}+c^{p}\left(d p_{i}+\frac{\left(A Q_{i 0}-A Q_{i t}\right)}{\sum_{j}^{n} \sum_{k}^{K} L_{i j k 0}}\right)
\end{gathered}
$$

\subsection{Economic Returns Objective}

The cost to produce an acre of the crop $j$ with irrigation practice $k$, excluding the irrigation costs, $c a_{j k}$, and the price per conventional unit of the crop, $p r_{j}$, are constant in real terms. We assume no productivity growth trend for the constant yield of crop $j$ per acre using irrigation practice $k$ at site $i, y_{i j k}$. Excluding the costs of irrigation, the net value for crop $j$ with irrigation practice $k$ is then $p r_{j} y_{i j k}-$ $c a_{j k}$ per acre. The constant purchase price for an acre-foot of off-farm water is $c^{o f w}$. The reservoir pumping cost per acre-foot is $c^{r w}$, and per acre capital and maintenance cost of a reservoir each period is $c^{r}$. We make monetary values over time comparable using the real discount factor, $\delta_{t}$.

Equation 7 indicates the economic objective to maximize the present value of farm profits over the fixed horizon $T$ by changing the amount of land in each crop, the off-farm water use, the reservoir water use, and groundwater usenamely, $L_{i j k t}, O F W_{i t}, R W_{i t}$, and $G W_{i t}$. The initial condition of the state variables and the nonnegativity constraints on land, water use, and the aquifer are shown in equation (8).

$$
\begin{array}{r}
\max _{L_{i j k t}, R W_{i t}, O F W_{i t}, G W_{i t}}: \sum_{t=1}^{T} \delta_{t}\left(\sum_{i=1}^{m} \sum_{j=1}^{n}\left(p r_{j} y_{i j k}-c a_{j k}\right) L_{i j k t}-c^{r} L_{i R t}\right. \\
\left.-c^{r w} R W_{i t}-c^{o f w} O F W_{i t}-G C_{i t} G W_{i t}\right)
\end{array}
$$

subject to:

$$
\begin{aligned}
L_{i j k 0} & =L_{0}^{i j k}, L_{i R 0}=0, A Q_{i 0} \\
& =A Q_{0}^{i}, L_{i j t} \geq 0, R W_{i t} \geq 0, O F W_{i t} \geq 0, G W_{i t} \geq 0, A Q_{i t} \geq 0
\end{aligned}
$$

and the spatial dynamics of land and irrigation (equations 1-6). 


\subsection{Off-Farm Water Demand Curve and Sensitivity Analyses}

The demand for off-farm water by the producers on the agricultural landscape is created by varying the price of an acre-foot of off-farm water from $\$ 5$ per acrefoot to $\$ 350$ per acre-foot with increments of $\$ 5$ per acre-foot. The pairing of the quantity demanded and the price per acre-foot of the off-farm water for each $\$ 5$ per acre-foot increment traces out the demand curve for the off-farm water. The quantity of water demanded from the irrigation water sources for each offfarm price increment indicates how much off-farm water supplants reservoir and groundwater.

To evaluate the availability of off-farm water use and irrigation practice adoption on land, reservoir, and groundwater use, and economic returns, the baseline, which assumes no off-farm and reservoir water use and no irrigation practice adoption (No OFW, No RES, No IP), is compared to the results of the technology and policy scenarios, for off-farm water prices of $\$ 50, \$ 125$, and $\$ 200$ per acre-foot.

\subsection{Technology Scenarios}

We assess the following technology scenarios: (1) off-farm water only (OFW, No RES, No IP); (2) off-farm and reservoir water only (OFW, RES, No IP); (3) off-farm and irrigation practice adoption only (OFW, No RES, IP); and (4) offfarm and reservoir water use and irrigation practice adoption (OFW, RES, IP). Additional sensitivity analyses examine the influence of reservoir cost/capacity and the rate of adoption of irrigation practices. The reservoir scenarios include low cost/high capacity and high cost/low capacity. The baseline rate of adoption, which is set exogenously in the model, has the percentage of the entire crop acreage on the landscape adopting alternative irrigation practices rise $20 \%$ every 10 years to $60 \%$ by the end of the 30 -year study period. The irrigation practices are attractive because irrigation costs fall more than the capital costs of the irrigation equipment rise. However, it takes time for producers to embrace new practices, and thus we constrain the rate of adoption by setting this constraint exogenously in the model. The sensitivity analyses change the rate of adoption so the rise in the percentage of the entire crop on the landscape using alternative irrigation practices is (1) $10 \%$ every 10 years to $30 \%$ by the end of the study period and (2) $30 \%$ every 10 years to $90 \%$ by the end of the study period.

\subsection{Policy Options}

The groundwater conservation policy options we consider are a reservoir construction cost share by modifying $c^{r}$, in addition to irrigation practice cost shares for land leveling, pipe hole selection program, surge valve, multiple inlet, and center pivot by modifying $c a_{j k}$. Another policy is a tax that raises the groundwater pumping cost $G C_{i t}$. The cost share for irrigation reservoir construction is $65 \%$, and the cost share for land leveling, pipe hole selection program, surge valve, multiple inlet, and center pivot is $60 \%$ 

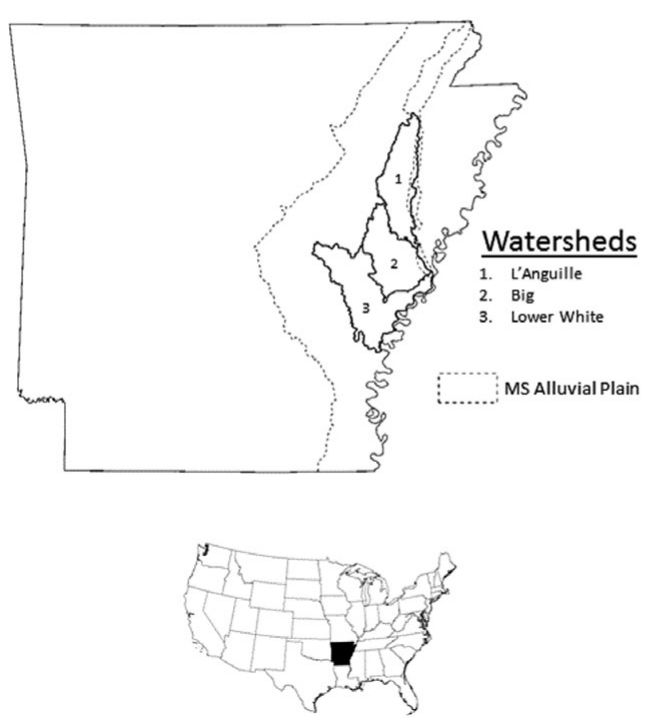

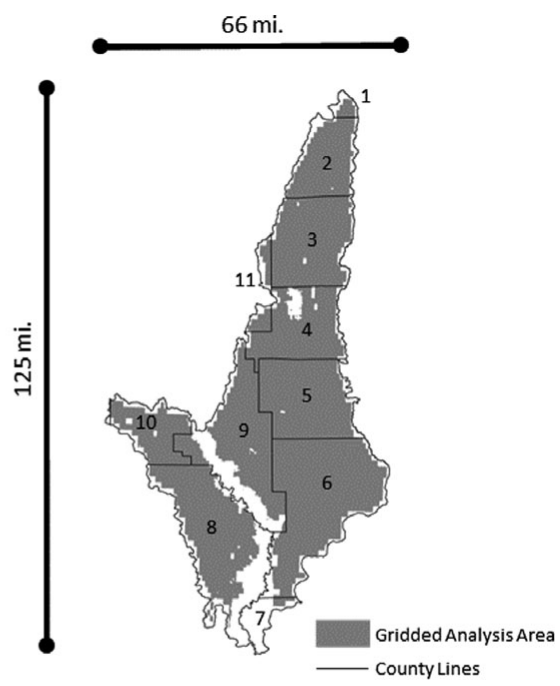

Counties

Figure 1. Three Eight-Digit Hydrologic Unit Code (HUC) Watersheds in the Mississippi Delta Region of Eastern Arkansas Define the Outer Boundary of the Study Area (an eight-digit HUC defines the drainage area of the subbasin of a river; county lines overlay the study area; public land and urban areas are excluded; and the location of the study area within the state of Arkansas is shown)

based on the Natural Resource Conservation Service rates (U.S. Department of Agriculture [USDA], Natural Resource Conservation Service, 2015). A tax that raises groundwater pumping costs by $26 \%$ is chosen to achieve groundwater conservation similar to the cost share on reservoir construction.

\section{Data}

Three eight-digit hydrologic unit code (HUC) watersheds comprise the study area where unsustainable groundwater use is occuring in the Arkansas delta (Figure 1). Eleven Arkansas counties overlap the watersheds, and 2,724 sites divide the study area to evaluate how farmers make decisions about crop allocation and water use on a spatially differentiated landscape. Table S1 in the online supplementary material has the acreage of each crop initially by site based on "2015 Cropland Data Layer" (Johnson and Mueller, 2010). The irrigated versus nonirrigated soybean acreage is based on the harvested acreage 
for 2010-2011 (USDA, National Agricultural Statistics Service, Delta Regional Office: Arkansas, 2015a, 2015b). The estimate of yield for each of the crops comes from the average county crop yields for the past 5 years (Division of Agriculture, University of Arkansas, 2015). After adjustment for inflation, the ownership and maintenance charges for the irrigation technologies, reservoirs, and wells and the costs of production for all crops are constant over time. With a 30-year Treasury bond yield over the last decade of 5\% (U.S. Department of the Treasury, 2015) less a long-run expectation for inflation of $3 \%$, the analysis uses a $2 \%$ real discount rate.

\subsection{Farm Production}

The farm production model parameters are shown in Table S2 in the online supplementary material. The Division of Agriculture, University of Arkansas (2015) has the 2015 Crop Enterprise Budgets estimates used for the costs of production by crop excluding irrigation costs. Labor, fuel, lube and oil, and poly-pipe for border irrigation plus the levee gates for the flood irrigation of rice all contribute to the costs of irrigation (Hogan et al., 2007). The wells, pumps, gearheads, and power units have purchase and maintenance costs that raise the per acre-foot costs of irrigation water. The Division of Agriculture, University of Arkansas (2015) has the average irrigation over the course of the growing season excluding natural rainfall. The crop prices come from the 5-year average of December futures prices for harvest time contracts for all crops (Great Pacific Trading Company, 2015). The depth to the water table and the corresponding fuel needed to raise water determines the fuel cost per acre-foot from the aquifer. A 100-foot well requires about 13 gallons of diesel per acre-foot, and a 200foot well requires about 26 gallons of diesel per acre-foot (Hogan et al., 2007). About 6 gallons of diesel is necessary to pump an acre-foot of water to and from a reservoir (Hogan et al., 2007). The U.S. Energy Information Administration (2015) indicates that diesel costs $\$ 3.77$ per gallon, and to account for oil and lube for irrigation equipment, we add $10 \%$ to the fuel costs (Hogan et al., 2007).

\subsection{Reservoir Use and Construction}

An acre of reservoir can hold about 16.5 acre-inches from natural rainfall $\left(\omega_{\text {min }}\right)$ without the collection of runoff from a tailwater recovery system (NOAA, National Centers for Environmental Information, 2014). With a tailwater recovery system, a reservoir can fill to a maximum capacity of 7.5 acre-feet per acre $\left(\omega_{\max }\right)$ over the course of a year (Smartt et al., 2002). For the low-end and high-end capacity of the reservoirs for the reservoir scenarios, a maximum annual capacity of 4 and 11 acre-feet per acre of reservoir is used, respectively.

The Modified Arkansas Off-Stream Reservoir Analysis (MARORA) (Smartt et al., 2002) tool estimates on-farm reservoir/tailwater recovery construction and maintenance costs for various size reservoirs. Most of the reservoir construction cost is associated with moving soil and this is updated to $\$ 1.2$ per cubic yard. 
The maintenance costs from MARORA include a pump for tailwater recovery and a pump for irrigation. The reservoir and tailwater recovery system capital cost is converted to an annual amortized cost plus maintenance cost of $\$ 377$ per acre of reservoir. An annual cost at the low end of $\$ 285$ and at the high end of $\$ 777$ per acre of reservoir for the reservoir scenarios is used.

\subsection{Groundwater Use and Recharge}

The depth to the water table and initial saturated thickness of the alluvial aquifer shown in Table S1 (in the online supplementary material) comes from the ANRC (2012). Overdraft of the aquifer makes the saturated thickness of the aquifer decline. The acreage of each site times the saturated thickness of the aquifer is the initial size of the aquifer under the site. Reed (2003) uses a calibrated model of recharge for the period 1994 to 1998 associated with precipitation and flow to or from surface streams to determine the natural recharge $\left(n r_{i}\right)$ of the alluvial aquifer.

Well pumping causes groundwater to flow from the surrounding sites in the aquifer into the sites with the depleted aquifer. The distance from the pump and the hydraulic diffusivity of the aquifer determine this underground flow of water. The hydraulic diffusivity divided by the square of the shortest distance between the pumped well and the surrounding sites indicates the proportion, $p_{i k}$, of the surrounding aquifer $i$ depleted because of pumping at a particular site $k$ (Kovacs et al., 2015). The ratio of the transmissivity and the specific yield of the unconfined alluvial aquifer is the hydraulic diffusivity (Barlow and Leake, 2012). The dimensionless ratio of water drainable by saturated aquifer material to the total volume of that material is the specific yield. Transmissivity is the product of hydraulic conductivity and saturated thickness, and the rate of groundwater flow per unit area under a hydraulic gradient is the hydraulic conductivity. Clark, Westerman, and Fugitt (2013) use spatially coarse pilot points to estimate the hydraulic conductivity.

\subsection{Alternative Irrigation Practice Adoption}

Conventional irrigation for furrow-irrigated soybeans, corn, and cotton in the Arkansas delta delivers irrigation water through equally sized holes punched into polyvinyl chloride plastic irrigation pipe (i.e., poly-pipe). The irrigation water flows from the holes in the poly-pipe laid at the top of the field down each furrow. Alternative irrigation practices for furrow-irrigated crops to reduce water use and potentially raise yield are center pivot, surge irrigation, precision leveling, and poly-pipe with computerized hole selection. A hanging sprinkler system that rotates circularly around a pivot is the center pivot. A variation on poly-pipe furrow irrigation is surge irrigation where water flowing from the poly-pipe is pulsed on and off to advance water down the furrow faster. Computerized pipehole selection is another variation of poly-pipe furrow irrigation that helps fully irrigate the field with less water by adjusting hole sizes on the tubes for different 
row lengths based on pressure changes along the tube. By smoothing the surface of the field, precision leveling increases the rate of flow and evenness of water down the furrow.

Flood is the conventional irrigation practice for rice, and alternative practices for rice are precision leveling, alternate wet-dry, and multiple-inlet flooding. The zero grade of rice paddies to provide uniform flood of the rice is the precision leveling. Alternate wetting and drying is a practice where soils drain intermittently during part of the rice life cycle rather than maintaining a continuous flood on the field. The release of floodwater evenly over the whole field through holes or gates in poly-pipe tube is multiple-inlet flooding.

Tables S3, S4, and S5 in the online supplementary material indicate how crop yield, irrigation water use, and production costs by crop change if producers adopt the alternative irrigation practices. The changes because of the irrigation practice adoptions are shown as adjustment coefficients to the conventional practice values. Within the model, the alternative irrigation practices improve farm profitability and lower water pumping costs, and this would make producers adopt them immediately even without cost-share assistance from the government. In practice, however, the rate of adoption takes time because education about the practices occurs gradually, and not all producers think alternative irrigation practices will help them.

\section{Results}

Tables 1 and 2 present the results of five model scenarios: (1) no off-farm water, reservoirs, or adoption of irrigation practices (No OFW, No RES, No IP); (2) adoption of off-farm water and no adoption of reservoirs or irrigation practices (OFW, No RES, No IP); (3) adoption of off-farm water and reservoirs and no adoption of irrigation practices (OFW, RES, No IP); (4) adoption of off-farm water, no adoption of reservoirs, and adoption of irrigation practices up to $60 \%$ of the entire landscape area by 2043 (OFW, No RES, IP); and (5) adoption of offfarm water, reservoirs, and irrigation practices up to $60 \%$ of the crop landscape by 2043 (OFW, RES, IP). The results represent the projected state of land use, water use, and economic returns for the year 2043 for each of the scenarios and for selected off-farm water prices of $\$ 50$ per acre-foot, $\$ 125$ per acre-foot, and $\$ 200$ per acre-foot. Figure 2 shows the demand curve for off-farm water by scenario, and Figure 3 presents the demand of water by source and scenario as a function of off-farm water prices.

For the entire landscape, the results indicate that, if priced competitively, offfarm water has the potential to become a relevant source of irrigation water. At $\$ 50$ per acre-foot, off-farm water becomes more than $50 \%$ of irrigation water used for the scenarios without irrigation practice adoption. Off-farm water provides 948,000 acre-feet or $57 \%$ of total water use in 2043 (Table 1), and 526,000 acre-feet or $45 \%$ of total water use when irrigation practices are 
Table 1. Impact of Reservoir Construction on Land and Water Use, and Economic Returns in 2043

\begin{tabular}{|c|c|c|c|c|c|c|c|}
\hline \multirow[b]{3}{*}{ Land Use (acres) } & \multirow[b]{3}{*}{ No OFW, No RES, No IPa } & \multicolumn{3}{|c|}{ OFW, No RES, No IP } & \multicolumn{3}{|c|}{ OFW, RES ${ }^{\mathrm{b}}$, No IP } \\
\hline & & \multicolumn{3}{|c|}{ Off-Farm Water Prices (\$/ac.-ft.) } & \multicolumn{3}{|c|}{ Off-Farm Water Prices (\$/ac.-ft.) } \\
\hline & & 50 & 125 & 200 & 50 & 125 & 200 \\
\hline Rice, conventional irrigation & 214,400 & 410,200 & 216,700 & 214,400 & 410,200 & 255,800 & 255,800 \\
\hline Rice, IP & & 0 & 0 & 0 & 0 & 0 & 0 \\
\hline Irrigated soybeans, conventional irrigation & 126,100 & 129,900 & 126,800 & 126,100 & 129,900 & 127,100 & 127,100 \\
\hline Irrigated soybeans, IP & & 0 & 0 & 0 & 0 & 0 & 0 \\
\hline Irrigated corn, conventional irrigation & 379,800 & 411,400 & 402,200 & 392,300 & 411,400 & 406,600 & 406,600 \\
\hline Irrigated corn, IP & & 0 & 0 & 0 & 0 & 0 & 0 \\
\hline Irrigated cotton, conventional irrigation & 94,844 & 96,613 & 97,360 & 94,840 & 96,613 & 97,943 & 97,943 \\
\hline Irrigated cotton, IP & & 0 & 0 & 0 & 0 & 0 & 0 \\
\hline Double crop soybean/wheat, conventional irrigation & 11,600 & 14,599 & 23,234 & 12,187 & 14,599 & 5,866 & 5,866 \\
\hline Double crop soybean/wheat, IP & & 0 & 0 & 0 & 0 & 0 & 0 \\
\hline Nonirrigated soybeans & 0 & 0 & 0 & 0 & 0 & 0 & 0 \\
\hline Nonirrigated sorghum & 314,400 & 78,395 & 274,900 & 301,300 & 78,395 & 233,400 & 233,400 \\
\hline Reservoirs & & 0 & 0 & 0 & 0 & 14,353 & 14,353 \\
\hline \multicolumn{8}{|l|}{ Water use (1,000 ac.-ft./year) } \\
\hline Annual water use & 1,145 & 1,674 & 1,186 & 1,159 & 1,674 & 1,275 & 1,275 \\
\hline Annual reservoir water use & 0 & 0 & 0 & 0 & 0 & 115 & 115 \\
\hline Annual groundwater use & 1,145 & 726 & 1,139 & 1,146 & 726 & 1,160 & 1,160 \\
\hline Annual off-farm water use & 0 & 948 & 47 & 13 & 948 & 0 & 0 \\
\hline Aquifer & 57,720 & 73,280 & 57,570 & 57,700 & 73,280 & 57,630 & 57,630 \\
\hline 30-Year farm net returns (million \$) & 4,469 & 5,024 & 4,500 & 4,472 & 5,024 & 4,546 & 4,546 \\
\hline
\end{tabular}

${ }^{a} I P$, irrigation practices; OFW, off-farm water; RES, reservoirs.

${ }^{\mathrm{b}}$ The baseline reservoir cost/capacity is $\$ 377$ per acre per year and 7.5 acre-feet of storage per acre. 
Table 2. Impact of Irrigation Practices on Land and Water Use, and Economic Returns in 2043

\begin{tabular}{|c|c|c|c|c|c|c|c|}
\hline \multirow[b]{3}{*}{ Land Use (acres) } & \multirow[b]{3}{*}{ No OFW, No RES, No IP } & \multicolumn{3}{|c|}{ OFW, No RES, IP } & \multicolumn{3}{|c|}{ OFW, RES ${ }^{c}, \mathrm{IP}^{\mathrm{b}}$} \\
\hline & & \multicolumn{3}{|c|}{ Off-Farm Water Prices (\$/ac.-ft.) } & \multicolumn{3}{|c|}{ Off-Farm Water Prices (\$/ac.-ft.) } \\
\hline & & 50 & 125 & 200 & 50 & 125 & 200 \\
\hline Rice, conventional irrigation & 214,400 & 0 & 0 & 0 & 0 & 0 & 0 \\
\hline Rice, IP & & 561,200 & 560,200 & 548,100 & 561,200 & 560,500 & 560,500 \\
\hline Irrigated soybeans, conventional irrigation & 126,100 & 52,151 & 49,823 & 49,297 & 52,151 & 50,177 & 50,177 \\
\hline Irrigated corn, conventional irrigation & 379,800 & 342,000 & 313,300 & 295,500 & 342,000 & 317,500 & 317,500 \\
\hline Irrigated corn, IP & & 0 & 19,200 & 29,200 & 0 & 13,000 & 13,000 \\
\hline Irrigated cotton, conventional irrigation & 94,844 & 0 & 0 & 0 & 0 & 0 & 0 \\
\hline Irrigated cotton, IP & & 123,500 & 105,200 & 107,400 & 123,500 & 111,200 & 111,200 \\
\hline Double crop soybean/wheat, conventional irrigation & 11,600 & 13,566 & 5,937 & 3,545 & 13,566 & 4,808 & 4,808 \\
\hline Double crop soybean/wheat, IP & & 0 & 0 & 0 & 0 & 0 & 0 \\
\hline Nonirrigated soybeans & 0 & 0 & 0 & 0 & 0 & 0 & 0 \\
\hline Nonirrigated sorghum & 314,400 & 48,747 & 87,410 & 108,100 & 48,747 & 72,793 & 72,791 \\
\hline \multicolumn{8}{|l|}{ Water use $(1,000 \mathrm{ac}-\mathrm{ft} . /$ year $)$} \\
\hline Annual water use & 1,145 & 1,174 & 1,137 & 1,111 & 1,174 & 1,141 & 1,141 \\
\hline Annual reservoir water use & 0 & 0 & 0 & 0 & 0 & 91 & 91 \\
\hline Annual groundwater use & 1,145 & 648 & 1,040 & 1,048 & 648 & 1,050 & 1,050 \\
\hline Annual off-farm water use & 0 & 526 & 97 & 63 & 526 & 0 & 0 \\
\hline Aquifer & 57,720 & 74,290 & 60,730 & 60,850 & 74,290 & 60,700 & 60,700 \\
\hline 30-Year farm net returns (million \$) & 4,469 & 7,091 & 6,748 & 6,672 & 7,091 & 6,783 & 6,783 \\
\hline
\end{tabular}

a IP, irrigation practices; OFW, off-farm water; RES, reservoirs.

${ }^{\mathrm{b}}$ The baseline rate of irrigation practice adoption is $60 \%$ of the crop landscape by 2043 .

${ }^{c}$ The baseline reservoir cost/capacity is $\$ 377$ per acre per year and 7.5 acre-feet of storage per acre. 


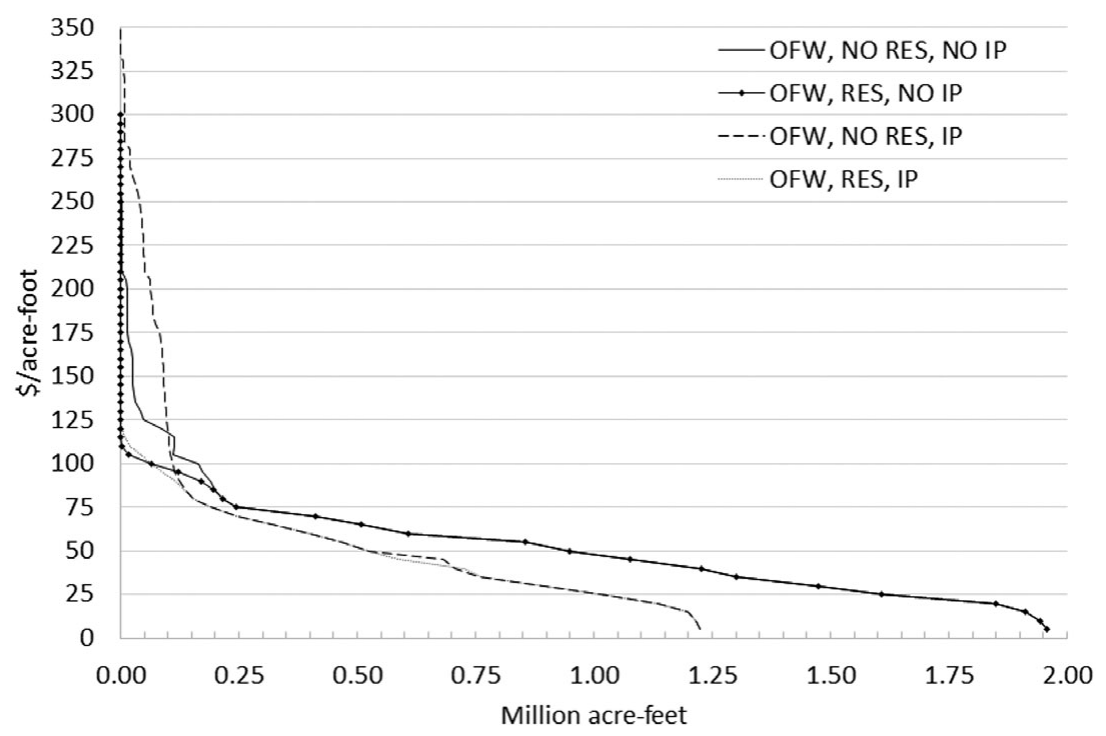

Figure 2. Off-Farm Water Demand Curves for Four Scenarios for the Study Area in 2043 (IP, irrigation practices; OFW, off-farm water; RES, reservoirs)

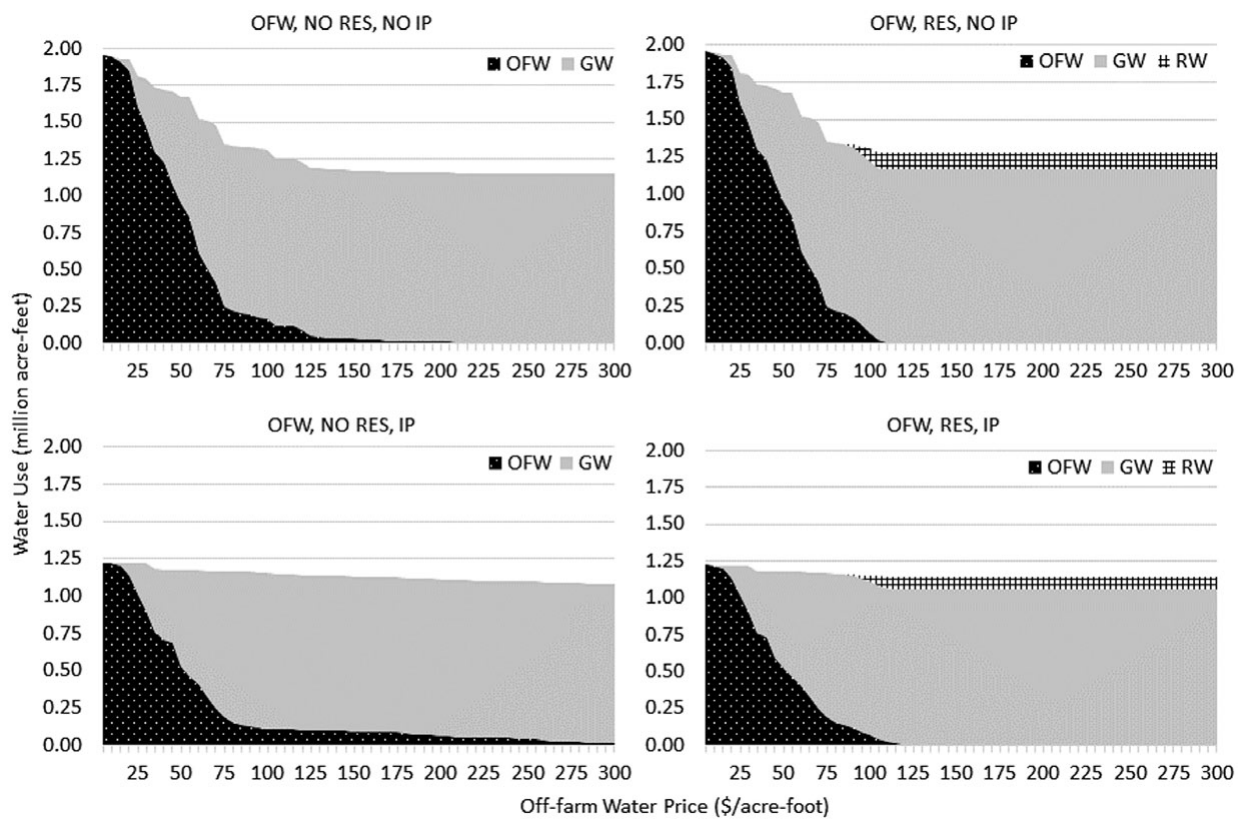

Figure 3. Water Use by Source for Four Scenarios as a Function of the Off-Farm Water Price for the Study Area in 2043(GW, groundwater; OFW, off-farm water; RW, reservoir water) 
allowed. The acreage of rice compared with the baseline without off-farm water expands by more than $90 \%$ at $\$ 50$ per acre-foot, only by $1 \%$ at $\$ 125$ per acre-foot, and not at all at $\$ 200$ per acre-foot. The amount of land in irrigated soybeans and irrigated corn increases by less than $4 \%$ and $9 \%$, respectively, for an off-farm water price of $\$ 50$ per acre-foot and by even less at higher prices for off-farm water. The land in nonirrigated sorghum falls by $75 \%$ at $\$ 50$ per acrefoot, by $13 \%$ at $\$ 125$ per acre-foot, and by $4 \%$ at $\$ 200$ per acre-foot. The crop choice is highly responsive to the price of off-farm water, which in turn affects the final level of the aquifer and the 30-year net returns.

The use of reservoirs affects the off-farm water demand only slightly and at high off-farm water prices. Reservoirs become a competitive source of water only at off-farm water prices above $\$ 75$ per acre-foot, reducing the intercept of the off-farm water demand curve to $\$ 125$ per acre-foot from $\$ 250$ per acrefoot (Figures 2 and 3). The adoption of irrigation practices affects the off-farm water demand curve in two distinct ways: (1) shifting it to the left at off-farm water prices below $\$ 75$ per acre-foot and, (2) without reservoirs making it very inelastic at higher prices, moving the intercept up to $\$ 345$ per acre-foot. The impact of irrigation practices on the elasticity of off-farm water demand at high prices is explained by the shift in land use generated by the adoption of irrigation practices that favor the expansion of rice, particularly in sites with highly depleted aquifers where off-farm water use persists even at such high prices.

Without off-farm water, reservoirs, and irrigation practices, we project that the volume of the aquifer will decrease to 57.7 million acre-feet by 2043, marking a $24 \%$ decrease relative to the initial 2013 level. At an off-farm water price of $\$ 125$ per acre-foot, the adoption of reservoirs slightly decreases the 2043 aquifer to 57.6 million acre-feet without the adoption of irrigation practices because the acreage of irrigated crops increases when reservoirs and off-farm water provide a backstop water source. At an off-farm water price of $\$ 50$ per acre-foot, the capacity of the aquifer in 2043 will be 74.3 million acre-feet and 73.3 million acre-feet with and without adoption of irrigation practices, respectively (Tables 1 and 2). This is an increase in the volume of the aquifer of the landscape by at least 15.6 million acre-feet by 2043 and significantly reduces its depletion, estimated at less than $4 \%$ relative to the 2013 level.

When groundwater is the sole irrigation source, rice acreage by 2043 is estimated at 214,400 acres or $19 \%$ of the total land used. The adoption of reservoirs at $\$ 125$ per acre-foot or greater for off-farm water increases rice acreage by $19 \%$ to 255,800 and corn acreage by $7 \%$ to 406,600 . However, the main boost in rice acres comes if off-farm water has a price in the range of $\$ 50$ per acre-foot. At that price, rice acreage increases by $91 \%$ to 410,200 acres, amounting to $36 \%$ of the total land use by 2043 (Table 1). Sorghum acreage follows an opposite trend than rice, becoming a dominant choice when only groundwater is available but decreasing as alternative water sources are available 
to grow irrigated crops. The adoption of irrigation practices (Table 2) changes land use by 2043 in two primary ways: (1) it increases the share of irrigated crops in the landscape to more than $90 \%$ of the total land use, and (2) it stabilizes the crop mix choice at different off-farm price levels. The adoption of irrigation practices results in an expansion of rice acreage up to almost half of the total land used in 2043. All rice and cotton acreage is expected to adopt some form of water-saving irrigation practice.

Table 3 shows that the cost/capacity of reservoirs has a modest influence on crop mix, water use, and farm net returns. Even at the low cost/high capacity of reservoirs, off-farm water at $\$ 50$ per acre-foot continues to be a better economic option than reservoirs. Low-cost/high-capacity reservoirs become a better option at higher off-farm water prices. At $\$ 125$ per acre-foot for offfarm water, reservoir water use increases to 168,000 acre-feet or $14 \%$ of annual water use, and the volume of the aquifer rises by 2.9 million acre-feet compared with the baseline reservoir and irrigation practices scenario (OFW, RES, IP; Table 2). At the high-cost/low-capacity reservoir scenario, producers continue to use off-farm water even at $\$ 200$ per acre-foot, and less than 1,000 acres of highcost/low-capacity reservoirs are constructed, but farm net returns fall less than $2 \%$ compared with the baseline reservoir scenario. The acreage of nonirrigated sorghum and cotton is most affected by reservoir cost/capacity at high off-farm water prices. Compared with the baseline reservoir cost/capacity at $\$ 125$ per acre-foot for off-farm water, the low-cost/high-capacity scenario has acreage in nonirrigated sorghum down by $25 \%$ and cotton up by $10 \%$, and in the highcost/low-capacity scenario, nonirrigated sorghum acreage is up by $20 \%$ and cotton acreage is down by $5 \%$.

The sensitivity analysis with respect to the rate of adoption of irrigation practices indicates the low-adoption scenario has a slightly larger depletion of the aquifer, a smaller share of irrigated crops, and lower farm net returns compared with the baseline reservoir and irrigation practices scenario (Table 4). The highadoption scenario, on the other hand, increases the share of irrigated crops, lowers the annual water use, helps replenish the aquifer, and increases net farm returns. At $\$ 50$ per acre-foot and compared with the baseline reservoir and irrigation practices scenario, annual off-farm water use increases by 15,000 acrefeet in the low-adoption scenario and decreases by 46,000 acre-feet in the highadoption scenario. The change in off-farm water use across adoption scenarios is a response to the amount of water an average acre of irrigated crop uses. At an off-farm water price of $\$ 125$ per acre-foot, the low-adoption scenario has 2,500 fewer acres of reservoirs because of a lower share of irrigated crops, and the high-adoption scenario has 249 more acres of reservoirs because of the higher share of irrigated crops. The policy implication of the change in the adoption rate is that the aquifer is largely unaffected, but the 30 -year net returns rise rapidly. The aquifer rises by only $1 \%$ to $2 \%$ as the rate of adoption increases because the share of irrigated acres expands as the efficiency of irrigation improves. The 
Table 3. Sensitivity Analysis on the Capacity and Cost of Reservoirs and the Impact on Land and Water Use, and Economic Returns in 2043

\begin{tabular}{|c|c|c|c|c|c|c|c|}
\hline \multirow[b]{3}{*}{ Land Use (acres) } & \multirow{3}{*}{$\begin{array}{l}\text { OFW, RES, IPa } \\
\text { At } \$ 125 / \text { ac.-ft. of } \\
\text { Off-Farm Water }\end{array}$} & \multicolumn{3}{|c|}{ Low Cost/High Capacity ${ }^{\mathrm{b}}$} & \multicolumn{3}{|c|}{ High Cost/Low Capacity ${ }^{c}$} \\
\hline & & \multicolumn{3}{|c|}{ Off-Farm Water Prices (\$/ac.-ft.) } & \multicolumn{3}{|c|}{ Off-Farm Water Prices (\$/ac.-ft.) } \\
\hline & & 50 & 125 & 200 & 50 & 125 & 200 \\
\hline Rice, conventional irrigation & 0 & 0 & 0 & 0 & 0 & 0 & 0 \\
\hline Rice, IP & 560,500 & 561,200 & 561,400 & 561,400 & 561,200 & 560,200 & 548,100 \\
\hline Irrigated soybeans, conventional irrigation & 50,177 & 52,151 & 50,198 & 50,198 & 52,151 & 49,823 & 49,297 \\
\hline Irrigated corn, conventional irrigation & 317,500 & 342,000 & 334,100 & 334,100 & 342,000 & 313,300 & 295,400 \\
\hline Irrigated corn, IP & 13,000 & 0 & 1,300 & 1,300 & 0 & 19,200 & 29,100 \\
\hline Irrigated cotton, conventional irrigation & 0 & 0 & 0 & 0 & 0 & 0 & 0 \\
\hline Irrigated cotton, IP & 111,200 & 123,500 & 122,000 & 122,000 & 123,500 & 105,200 & 107,500 \\
\hline Double crop soybean/wheat, conventional irrigation & 4,808 & 13,566 & 2,915 & 2,915 & 13,566 & 5,937 & 3,545 \\
\hline Double crop soybean/wheat, IP & 0 & 0 & 0 & 0 & 0 & 0 & 0 \\
\hline Nonirrigated soybeans & 0 & 0 & 0 & 0 & 0 & 0 & 0 \\
\hline Nonirrigated sorghum & 72,793 & 48,747 & 54,815 & 54,815 & 48,747 & 87,410 & 107,300 \\
\hline \multicolumn{8}{|l|}{ Water use (1,000 ac.-ft./year) } \\
\hline Annual water use & 1,141 & 1,174 & 1,156 & 1,156 & 1,174 & 1,137 & 1,111 \\
\hline Annual reservoir water use & 91 & 0 & 168 & 168 & 0 & 0 & 5 \\
\hline Annual groundwater use & 1,050 & 648 & 988 & 988 & 648 & 1,040 & 1,048 \\
\hline Annual off-farm water use & 0 & 526 & 0 & 0 & 526 & 97 & 58 \\
\hline Aquifer & 60,700 & 74,290 & 63,600 & 63,600 & 74,290 & 60,730 & 60,850 \\
\hline 30-Year farm net returns (million \$) & 6,783 & 7,091 & 6,850 & 6,850 & 7,091 & 6,748 & 6,673 \\
\hline
\end{tabular}

${ }^{a}$ IP, irrigation practices; OFW, off-farm water; RES, reservoirs.

${ }^{\text {b }}$ The low-end reservoir cost/capacity is $\$ 285$ per acre per year and 4 acre-feet of storage per acre.

${ }^{\mathrm{c}}$ The high-end reservoir cost/capacity is $\$ 777$ per acre per year and 11 acre-feet of storage per acre. 
Table 4. Sensitivity Analysis on the Rate of Adoption of Irrigation Practices and Its Impact on Land and Water Use, and Economic Returns in 2043

\begin{tabular}{|c|c|c|c|c|c|c|c|}
\hline \multirow[b]{3}{*}{ Land Use (acres) } & \multirow{3}{*}{$\begin{array}{l}\text { OFW, RES, IP } \\
\text { At } \$ 125 / \text { ac.-ft. of } \\
\text { Off-Farm Water }\end{array}$} & \multicolumn{3}{|c|}{ Low Rate of Adoption of $\mathrm{IP}^{\mathrm{b}}$} & \multicolumn{3}{|c|}{ High Rate of Adoption of $\mathrm{IP}^{\mathrm{b}}$} \\
\hline & & \multicolumn{3}{|c|}{ Off-Farm Water Prices (\$/ac.-ft.) } & \multicolumn{3}{|c|}{ Off-Farm Water Prices (\$/ac.-ft.) } \\
\hline & & 50 & 125 & 200 & 50 & 125 & 200 \\
\hline Rice, conventional irrigation & 0 & 69,571 & 23,460 & 23,460 & 0 & 0 & 0 \\
\hline Rice, IP & 560,500 & 340,629 & 337,640 & 337,640 & 561,900 & 560,700 & 560,600 \\
\hline Irrigated soybeans, conventional irrigation & 50,177 & 130,100 & 126,400 & 126,400 & 52,012 & 50,249 & 50,249 \\
\hline Irrigated soybeans, IP & 0 & 0 & 0 & 0 & 0 & 0 & 0 \\
\hline Irrigated corn, conventional irrigation & 317,500 & 411,400 & 406,500 & 406,500 & 18,807 & 5,530 & 5,427 \\
\hline Irrigated corn, IP & 13,000 & 0 & 0 & 0 & 322,393 & 329,770 & 329,873 \\
\hline Irrigated cotton, conventional irrigation & 0 & 94,896 & 91,203 & 91,203 & 0 & 0 & 0 \\
\hline Irrigated cotton, IP & 111,200 & 1,717 & 4,685 & 4,685 & 142,600 & 136,500 & 136,500 \\
\hline Double crop soybean/wheat, conventional irrigation & 4,808 & 14,483 & 5,503 & 5,503 & 425 & 144 & 144 \\
\hline Double crop soybean/wheat, IP & 0 & 0 & 0 & 0 & 0 & 0 & 0 \\
\hline Nonirrigated soybeans & 0 & 0 & 0 & 0 & 0 & 0 & 0 \\
\hline Nonirrigated sorghum & 72,793 & 78,374 & 137,100 & 137,100 & 42,869 & 46,807 & 46,803 \\
\hline Reservoirs & 11,133 & 0 & 8,608 & 8,608 & 0 & 11,382 & 11,490 \\
\hline \multicolumn{8}{|l|}{ Water use (1,000 ac.-ft./year) } \\
\hline Annual water use & 1,141 & 1,239 & 1,102 & 1,102 & 1,082 & 1,066 & 1,066 \\
\hline Annual reservoir water use & 91 & 0 & 70 & 70 & 0 & 93 & 93 \\
\hline Annual groundwater use & 1,050 & 698 & 1,032 & 1,032 & 602 & 972 & 972 \\
\hline Annual off-farm water use & 0 & 541 & 0 & 0 & 480 & 1 & 0 \\
\hline Aquifer & 60,700 & 73,530 & 60,170 & 60,170 & 74,560 & 61,630 & 61,640 \\
\hline 30-Year farm net returns (million \$) & 6,783 & 6,113 & 5,795 & 5,795 & 7,729 & 7,425 & 7,425 \\
\hline
\end{tabular}

a IP, irrigation practices; OFW, off-farm water; RES, reservoirs.

${ }^{b}$ The low and high rates of irrigation practice adoption are $30 \%$ and $90 \%$ of the crop landscape by 2043 , respectively. 
30 -year net returns rise by $10 \%$ to $17 \%$ as the rate of adoption goes up because more high-value irrigated crops are grown at a lower irrigation cost.

Table 5 presents the influence of water conservation policies when off-farm water and reservoir water are available at the baseline reservoir and irrigation practices scenario (“OFW, RES, IP"). Only three policies, either cost-sharing reservoir construction and land leveling or the tax on groundwater use, have a modest effect on land and water use and farm and government returns. At \$125 per acre-foot for off-farm water, the reservoir cost-share program contributes to doubling the reservoir acreage from 11,000 to 22,100 acres, and the aquifer rises by 3.9 million acre-feet. It also changes land use in favor of irrigated crops, most notably cotton, at the expense of nonirrigated sorghum. The program costs the government $\$ 159$ million and improves farm returns by $\$ 82$ million, meaning there is a cost to society of the reservoir policy of $\$ 77$ million. Dividing the cost to society by the 3.9 million acre-feet of groundwater saved means a cost of $\$ 19.9$ per acre-foot.

Land leveling is the only efficient irrigation practice adopted in the baseline reservoir and irrigation practices scenario. At $\$ 125$ per acre-foot of off-farm water, the cost share on land leveling leads to an expansion of irrigated crops, most notably cotton; a modest expansion of total water use supported by reservoir and groundwater; and a lower aquifer. Hence, at high off-farm water prices, the cost share on land leveling exerts changes in water use that are a cost to society without any increase in the aquifer. The tax has a stronger influence on the aquifer at low off-farm water prices, resulting in 5.5 million acre-feet of groundwater saved at $\$ 50$ per acre-foot of off-farm water, relative to 3.9 million acre-feet of groundwater saved at $\$ 125$ per acre-foot of off-farm water. The tax policy achieves groundwater conservation at a cost to society of $\$ 4.3$ per acrefoot and $\$ 8.3$ per acre-foot when off-farm water prices are $\$ 50$ per acre-foot and $\$ 125$ per acre-foot, respectively. An off-farm water price of $\$ 50$ per acrefoot rather than $\$ 125$ per acre-foot raises the aquifer by 13.6 million acre-feet with no tax on groundwater use, and by 15.2 million acre-feet when combined with a tax on groundwater use. This suggests that a government subsidy to make off-farm water prices lower may be the most cost-effective way to preserve the aquifer.

\section{Discussion and Conclusion}

We examine frequently proposed recommendations to address the problem of aquifer overdraft in the Arkansas delta over 30 years that include the use of off- and on-farm surface water, more efficient irrigation technologies, and water conservation policies. These recommendations are intended to reduce groundwater pumping and increase farm net returns, but our results suggest that the aquifer is not always conserved through the use of surface water. The reason for the lack of aquifer conservation with the conjunctive use of surface water is 
Table 5. Water Conservation Policies Influence on Reservoir Construction, Aquifer Capacity, and Economic Returns by 2043

\begin{tabular}{|c|c|c|c|c|c|c|c|c|}
\hline \multirow[b]{2}{*}{ Land Use (acres) } & \multicolumn{4}{|c|}{ Off-Farm Water Price \$50/ac.-ft. } & \multicolumn{4}{|c|}{ Off-Farm Water Price \$125/ac.-ft. } \\
\hline & OFW, RES, IP & CS RES ${ }^{b}$ & CS LL $L^{c}$ & $\mathrm{GWT}^{\mathrm{d}}$ & OFW, RES, IP & CS RES ${ }^{b}$ & CS LL ${ }^{c}$ & GWT $^{d}$ \\
\hline Rice, IP & 561,200 & 561,200 & 561,200 & 561,200 & 560,500 & 561,300 & 560,800 & 558,000 \\
\hline Irrigated soybeans, conventional irrigation & 52,151 & 52,114 & 52,151 & 51,963 & 50,177 & 50,143 & 50,177 & 49,403 \\
\hline Irrigated corn, conventional irrigation & 342,000 & 342,000 & 342,000 & 342,000 & 317,500 & 329,300 & 324,500 & 299,500 \\
\hline Irrigated corn, IP & 0 & 0 & 0 & 0 & 13,000 & 3,400 & 5,500 & 20,200 \\
\hline Irrigated cotton, IP & 123,500 & 123,500 & 123,500 & 123,500 & 111,200 & 120,000 & 118,400 & 106,500 \\
\hline $\begin{array}{l}\text { Double crop soybean/wheat, conventional } \\
\text { irrigation }\end{array}$ & 13,566 & 13,566 & 13,566 & 13,634 & 4,808 & 3,413 & 2,331 & 2,211 \\
\hline Nonirrigated sorghum & 48,747 & 48,747 & 48,747 & 48,867 & 72,793 & 51,525 & 68,099 & 91,435 \\
\hline Reservoirs & 0 & 37 & 0.0 & 0.0 & 11,133 & 22,099 & 11,326 & 13,897 \\
\hline Water use (1,000 ac.-ft./year) & 0 & & & & 0 & & & \\
\hline Annual water use & 1,174 & 1,174 & 1,174 & 1,174 & 1,141 & 1,152 & 1,146 & 1,119 \\
\hline Annual reservoir water use & 0 & 0.3 & 0 & 0 & 91 & 182 & 92 & 115 \\
\hline Annual groundwater use & 648 & 648 & 648 & 511 & 1,050 & 970 & 1,054 & 1,004 \\
\hline 30-Year farm net returns $(\text { million } \$)^{\mathrm{e}}$ & 7,091 & 7,091 & 7,159 & 6,998 & 6,783 & 6,866 & 6,851 & 6,509 \\
\hline 30-Year government revenue (million \$) & - & -0.1 & -67.8 & 69.4 & - & -159.4 & -67.5 & 242.6 \\
\hline $\begin{array}{l}\text { Groundwater conservation cost } \\
\quad(\$ / \text { acre-foot })^{\mathrm{f}}\end{array}$ & - & $\begin{array}{l}\text { No } \\
\text { ground-water } \\
\text { conserved }\end{array}$ & $\begin{array}{l}\text { No } \\
\text { ground-water } \\
\text { conserved }\end{array}$ & 4.3 & - & 19.9 & $\begin{array}{l}\text { No } \\
\text { ground-water } \\
\text { conserved }\end{array}$ & 8.3 \\
\hline
\end{tabular}

a IP, irrigation practices; OFW, off-farm water; RES, reservoirs.

${ }^{\mathrm{b}}$ The cost share is $65 \%$ for irrigation reservoir construction (U.S. Department of Agriculture, Natural Resource Conservation Service, 2015). CS, cost share.

${ }^{\mathrm{c}}$ The cost share is $60 \%$ for land leveling (U.S. Department of Agriculture, Natural Resource Conservation Service, 2015). LL, land leveling.

${ }^{\mathrm{d}} \mathrm{A}$ tax on groundwater pumping costs $(26 \%)$ is chosen to achieve groundwater conservation similar to the cost share on reservoirs at an off-farm water price of \$125. GWT, groundwater tax.

'The farm net returns include the payments to or receipts from the government because of the policy.

${ }^{\mathrm{f}}$ Groundwater conservation cost is calculated as the policy cost (which is the farm net returns in the baseline less the farm net returns plus government revenue for each policy scenario) divided by the change in aquifer level between the policy option and the baseline. 
that this changes the crop mix on the landscape toward more irrigation-intensive crops with greater net returns. This is the case for the agricultural landscape with and without reservoirs when the off-farm water price is $\$ 125$ per acre-foot or greater. The price of surface water from either on- or off-farm sources needs to be low enough to generate a significant shift away from the groundwater as the crops grown on the landscape become more irrigation intensive.

The adoption of efficient irrigation practices increases both economic returns and the aquifer in spite of a major shift into irrigation-intensive crops. The irrigation practices allow more high-valued crops at a low cost to be grown with less burden on the aquifer, although the increase in the aquifer would have been more substantial without the shift into irrigation-intensive crops. The rate of adoption of the irrigation practices is positively associated with farm net returns because the irrigation practice adoption occurs mostly in rice and corn where lower irrigation costs boost net returns, but the rise in the aquifer is small because of the expansion of rice and corn acres. The policy implication of this is that encouraging the adoption of irrigation practices may be better for aquifer conservation than the development of surface water, but this hinges on how efficient these irrigation practices are at reducing water applied. Also, policy makers should look for ways to combine the use of off- and on-farm surface water and irrigation practices because these are complementary at achieving the goal of aquifer conservation.

The policy options to create an incentive for producers to lower groundwater use indicate that only a tax on groundwater use raises the aquifer at an offfarm water price of $\$ 50$ per acre-foot and that only the cost share on reservoir construction and the tax on groundwater use raise the aquifer at an off-farm water price of $\$ 125$ per acre-foot. This suggests that incentive policies are more effective or only effective if the off-farm water price is high. The cost share on the land-leveling irrigation practice used principally in rice makes rice acreage and groundwater use increase, and the policy is thus not effective for aquifer conservation even though each acre of rice uses less groundwater than before. The cost share on reservoir construction and the tax on groundwater use can both conserve groundwater at a cost to society, but the tax on groundwater use is more cost-effective because there is a direct incentive to reduce the resource of concern.

Ding and Peterson (2012) find that a cost-share program to improve irrigation efficiency or an incentive program to switch to dryland production can effectively reduce groundwater use, although the incentive program is less able to reduce water use when irrigated crop prices are high. We find the availability of surface water at $\$ 50$ per acre-foot means a cost-share program for irrigation efficiency has no influence on groundwater use, whereas at $\$ 125$ per acre-foot of offfarm water, the cost-share program increases groundwater use in the Arkansas delta. Landscape-wide adoption of efficient irrigation practices increases both aquifer volume and economic returns by having all crop acres use less water, 
but the cost-share programs for these irrigation practices do not conserve the aquifer because of extensive (fewer nonirrigated crops) and intensive margin changes that favor irrigation-intensive crops. Recent empirical analysis observes this finding in western Kansas where cost-share subsidized conversion from traditional to higher-efficiency dropped-nozzle center pivot irrigation systems increased groundwater extraction (Pfeiffer and Lin, 2014).

Our modeling of on- and off-farm surface water use supports the finding that irrigation investment, although effective at raising economic returns, does not necessarily reduce groundwater use (Huffaker and Whittlesey, 2000; Pfeiffer and Lin, 2014; Scheierling, Young, and Cardon, 2006; Ward and Pulido-Velazquez, 2008). Investment in water storage and greater irrigation efficiency is likely to enhance economic returns through higher yields, the planting of more valuable crops, and lower costs of irrigation water, but adjustments at the margins can negate the conservation aims. Publicly funded projects with the goal of aquifer conservation that provide off-farm water to farmers should be sure that the price charged for the off-farm water is low enough to dissuade groundwater extraction after changes in land use occur.

Future research could look at the return on investment in off-farm surface water by modeling a supply curve for off-farm water for farmers throughout the landscape. A comparison of long-run return on investment for on- and offfarm water or for more efficient irrigation practices would help policy makers prioritize where to direct scarce conservation funds. These analyses should be careful to account for changes in land use at all margins and to examine the sensitivity to energy and crop price changes. Another extension is to make the rate of adoption of efficient irrigation practices around the landscape based on the spatial proximity to farms that already use the practices. The spatial diffusion of irrigation practices then influences the equilibrium price for off-farm water, and this has repercussions on the level of groundwater extraction and economic returns.

\section{Supplementary material}

To view supplementary material for this article, please visit https://doi.org/10. 1017/aae.2016.39

\section{References}

Arkansas Natural Resources Commission (ANRC). Arkansas Ground-Water Protection and Management Report for 2011. Little Rock, AR: ANRC, 2012.

Arkansas Natural Resources Commission (ANRC). Arkansas Water Plan Update 2014. Little Rock, AR: ANRC, 2014.

Barlow, P.M., and S.A. Leake. Streamflow Depletion by Wells-Understanding and Managing the Effects of Groundwater Pumping on Streamflow. Reston, VA: U.S. Geological Survey, Circular 1376, 2012. 
Caswell, M.F., and D. Zilberman. "The Effects of Well Depth and Land Quality on the Choice of Irrigation Technology." American Journal of Agricultural Economics 68,4(1986):321-344.

Clark, B.R., D.A. Westerman, and D.T. Fugitt. Enhancements to the Mississippi Embayment Regional Aquifer Study (MERAS) Groundwater-Flow Model and Simulations of Sustainable Water-Level Scenarios. Reston, VA: U.S. Geological Survey, Scientific Investigations Report 2013-5161, 2013.

Ding, Y., and J.M. Peterson. "Comparing the Cost-Effectiveness of Water Conservation Policies in a Depleting Aquifer: A Dynamic Analysis of the Kansas High Plains.” Journal of Agricultural and Applied Economics 44,2(2012):223-34.

Division of Agriculture, University of Arkansas. 2015 Crop Enterprise Budgets. Little Rock: Division of Agriculture, University of Arkansas, AG-1302, 2015. Internet site: https:/www.uaex.edu/farm-ranch/economics-marketing/farm-planning/ budgets/Budget_Text_2015.pdf (Accessed January 2016).

Great Pacific Trading Company. "Charts and Quotes." November 2015. Internet site: http://www.rmbgroup.com/ (Accessed January 2016).

Hill, J., E. Wailes, M. Popp, J. Popp, J. Smartt, K. Young, and B. Watkins. "Surface Water Diversion Impacts on Farm Income and Sources of Irrigation Water: The Case of the Grand Prairie in Arkansas." Journal of Soil and Water Conservation 61,4(2006):18591.

Hogan, R., S. Stiles, P. Tacker, E. Vories, and K. J. Bryant. Estimating Irrigation Costs. Little Rock, AR: Arkansas Cooperative Extension Service, FSA28-PD-6-07RV, 2007.

Huffaker, R.G., and N.K. Whittlesey. "Agricultural Water Conservation Legislation: Will It Save Water?” Choices 10,4(1995):24-28.

. "The Allocative Efficiency and Conservation Potential of Water Laws Encouraging Investments in On-Farm Irrigation Technology.” Agricultural Economics 24,1(2000):4760.

Johnson, D.M., R. Mueller. “The 2009 Cropland Data Layer.” Photogrammetric Engineering and Remote Sensing 76,11(November 2010):1201-5.

Kovacs, K., and M. Mancini. "Conjunctive Water Management to Sustain Agricultural Economic Returns and a Shallow Aquifer at the Landscape Level." Journal of Soil and Water Conservation 72,3(2017).

Kovacs, K., M. Popp, K. Brye, and G. West. "On-Farm Reservoir Adoption in the Presence of Spatially Explicit Groundwater Use and Recharge." Journal of Agricultural and Resource Economics 40,1(2015):23-49.

Kovacs, K., E. Wailes, G. West, J. Popp, and K. Bektemirov. “Optimal Spatial-Dynamic Management of Groundwater Conservation and Surface Water Quality with OnFarm Reservoirs." Journal of Agricultural and Applied Economics 46,4(2014): $1-29$.

Kuwayama, Y., and N. Brozović. "The Regulation of a Spatially Heterogeneous Externality: Tradable Groundwater Permits to Protect Streams." Journal of Environmental Economics and Management 66,2(2013):364-82.

Moore, M.R., N.R. Gollehon, and M.B. Carey. "Multicrop Production Decisions in Western Irrigated Agriculture: The Role of Water Price." American Journal of Agricultural Economics 76,4(1994):859-74.

National Oceanic and Atmospheric Administration, National Centers for Environmental Information. "Climate Data Online Search.” Internet site: http://www.ncdc.noaa.gov/ cdo-web/search?datasetid=GHCNDMS (Accessed October 2014). 
Pfeiffer, L., and C.-Y.C. Lin. "Does Efficient Irrigation Technology Lead to Reduced Groundwater Extraction? Empirical Evidence.” Journal of Environmental Economics and Management 67,2(2014):189-208.

Reed, T.B. Recalibration of a Ground-Water Flow Model of the Mississippi River Valley Alluvial Aquifer of Northeastern Arkansas, 1918-1998, with Simulations of Water Levels Caused by Projected Ground-Water Withdrawals through 2049. Little Rock, AR: U.S. Geological Survey, Water Resources Investigations Report 03-4109, 2003.

Schaible, G.D., and M.P. Aillery. Water Conservation in Irrigated Agriculture: Trends and Challenges in the Face of Emerging Demands. Washington, DC: U.S. Department of Agriculture, Economic Research Service, Economic Information Bulletin No. 99, September 2012.

Scheierling, S.M., R.A. Young, and G.E. Cardon. "Public Subsidies for Water Conserving Irrigation Investments: Hydrologic, Agronomic, and Economic Assessment.” Water Resources Research 42,3(2006):W03428. doi:10.1029/2004WR003809.

Smartt, J.H., E.J. Wailes, K.B. Young, and J.S. Popp. MARORA (Modified Arkansas OffStream Reservoir Analysis) Program Description and User's Guide. Unpublished manuscript, Fayetteville, AR: Department of Agricultural Economics and Agribusiness, University of Arkansas, 2002.

U.S. Department of Agriculture, National Agricultural Statistics Service, Delta Regional Office: Arkansas. "Soybeans - Irrigated.” Internet site: https://www.nass.usda.gov/Statistics_ by_State/Arkansas/Publications/County_Estimates/(Accessed November 2015a).

U.S. Department of Agriculture, National Agricultural Statistics Service, Delta Regional Office: Arkansas. "Soybeans - Non-Irrigated." Internet site: https://www.nass.usda. gov/Statistics_by_State/Arkansas/Publications/County_Estimates/(Accessed November 2015b).

U.S. Department of Agriculture, Natural Resources Conservation Service, Arkansas. "2015 EQIP Conservation Practices and Payment Rates.” Internet site: https://www.nrcs.usda. gov/wps/portal/nrcs/detail/ar/home/?cid=STELPRDB1240703 (Accessed August 2015).

U.S. Department of the Treasury. “Interest Rate Statistics.” Internet site: http://www.treasury. gov/resource-center/data-chart-center/interest-rates/Pages/default.aspx (Accessed December 2015).

U.S. Energy Information Administration. "Gasoline and Diesel Fuel Update.” Internet site: http://www.eia.gov/petroleum/gasdiesel/ (Accessed November 2015).

Wailes, E.J., J. Popp, K.B. Young, and J. Smartt. "Economics of On-Farm Reservoirs and Other Water Conservation Improvements on Arkansas Rice Farms.” B.R. Wells Rice Research Studies 2003. R.J. Norman, J.-F. Meullenet, and K.A.K. Moldenhauer, eds. Arkansas Agricultural Experiment Station Research Series 517. Fayetteville, AR: Agricultural Experiment Station, Division of Agriculture, University of Arkansas, 2004, pp. 426-32.

Wang, C., and E. Segarra. "The Economics of Commonly Owned Groundwater When User Demand Is Perfectly Inelastic.” Journal of Agricultural and Resource Economics 36,1(2011):95-120.

Ward, F.A., and M. Pulido-Velazquez. "Water Conservation in Irrigation Can Increase Water Use." Proceedings of the National Academy of Sciences of the United States of America 105,47(2008):18215-20. 